\title{
Pengaruh Ukuran Perusahaan, Kepemilikan Manajerial, Dan Komite Audit Terhadap Kinerja Keuangan Perusahaan
}

\author{
Mulia Alim 1 ) \\ muliaalim@umt.ac.id \\ Assyifa') $^{20}$ \\ assyifafatirahma@gmail.com \\ FEB Universitas Muhammadiyah Tangerang
}

\begin{abstract}
Company performance is a picture of the financial condition of a company that is analyzed by financial analysis tools, so that it can be known about the good and bad financial condition of a company that reflects work performance in a certain period. An assessment of company performance is needed because performance reflects the company's ability to manage and allocate its resources. Companies with a high percentage of foreign ownership are suspected to be able to increase the company's performance because management with foreign ownership can be more focused and more efficient in directing the company's operational activities, so that the goal of maximizing profit can be achieved. Research on financial performance needs to be done because it can reflect the success of a company in generating profits and bearing in mind the company's main goal is to prosper shareholders by continuously multiplying the company's wealth.
\end{abstract}

Keywords : company size, managerial ownership, audit committee, financial performance

\begin{abstract}
Abstraksi
Kinerja perusahaan merupakan suatu gambaran tentang kondisi keuangan suatu perusahaan yang dianalisis dengan alat-alat analisis keuangan, sehingga dapat diketahui mengenai baik buruknya keadaan keuangan suatu perusahaan yang mencerminkan prestasi kerja dalam periode tertentu. Penilaian terhadap kinerja perusahaan diperlukan karena kinerja merefleksikan kemampuan perusahaan dalam mengelola dan mengalokasikan sumber dayanya. Perusahaan dengan persentase kepemilikan asing yang tinggi diduga dapat menigkatkan kinerja perusahaan karena manajemen dengan kepemilikan asing dapat lebih fokus dan lebih efisien dalam mengarahkan kegiatan operasional perusahaan, sehingga tujuan memaksimalkan profit dapat tercapai. Penelitian mengenai kinerja keuangan perlu dilakukan karena dapat merefleksikan keberhasilan suatu perusahaan dalam menghasilkan laba dan mengingat tujuan utama perusahaan adalah untuk mensejahterakan para pemegang saham dengan terus melipatgandakan kekayaan perusahaan.
\end{abstract}

Keywords : Ukuran perusahaan, Kepemilikan manajerial, komite audit, kinerja keuangan 


\section{PENDAHULUAN}

Pada era globalisasi ini keunggulan kompetitif menjadi suatu hal penting bagi perusahaan yang ingin tetap bertahan dan bersaing di pasar global. Keunggulan kompetitif atau keunggulan bersaing (competitive advantage) adalah kemampuan yang diperoleh melalui karakteristik dan sumber daya suatu perusahaan untuk memiliki kinerja yang lebih tinggi dibandingkan perusahaan lain pada industri atau pasar yang sama (id.wikipedia.org). Oleh karena itu untuk mengetahui keberhasilan kinerja perusahaan dapat dilihat dari kinerja keuangan perusahaan tersebut.

Kinerja keuangan melihat pada laporan keuangan yang dimiliki perusahaan/badan usaha yang bersangkutan dan itu tercermin dari informasi yang diperoleh pada balance sheet (neraca), income statement (laporan laba rugi), dan cash flow statement (laporan arus kas) serta hal-hal lain yang turut mendukung sebagai penguat penilaian financial performance tersebut (Fahmi, 2012) dalam (Sufiyati, 2016). Laporan keuangan dianggap menjadi salah satu cara yang fleksibel dan sederhana untuk para investor karena dapat memberikan jawaban mengenai kondisi perusahaan tersebut. Salah satunya yaitu melihat pada laporan laba rugi.

Berikut ini adalah fluktuasi laba pada perusahaan manufaktur di bursa efek indonesia pada periode 2015-2017. Data tersebut diambil dari laporan keuangan yang dinilai dalam satuan mata uang rupiah.

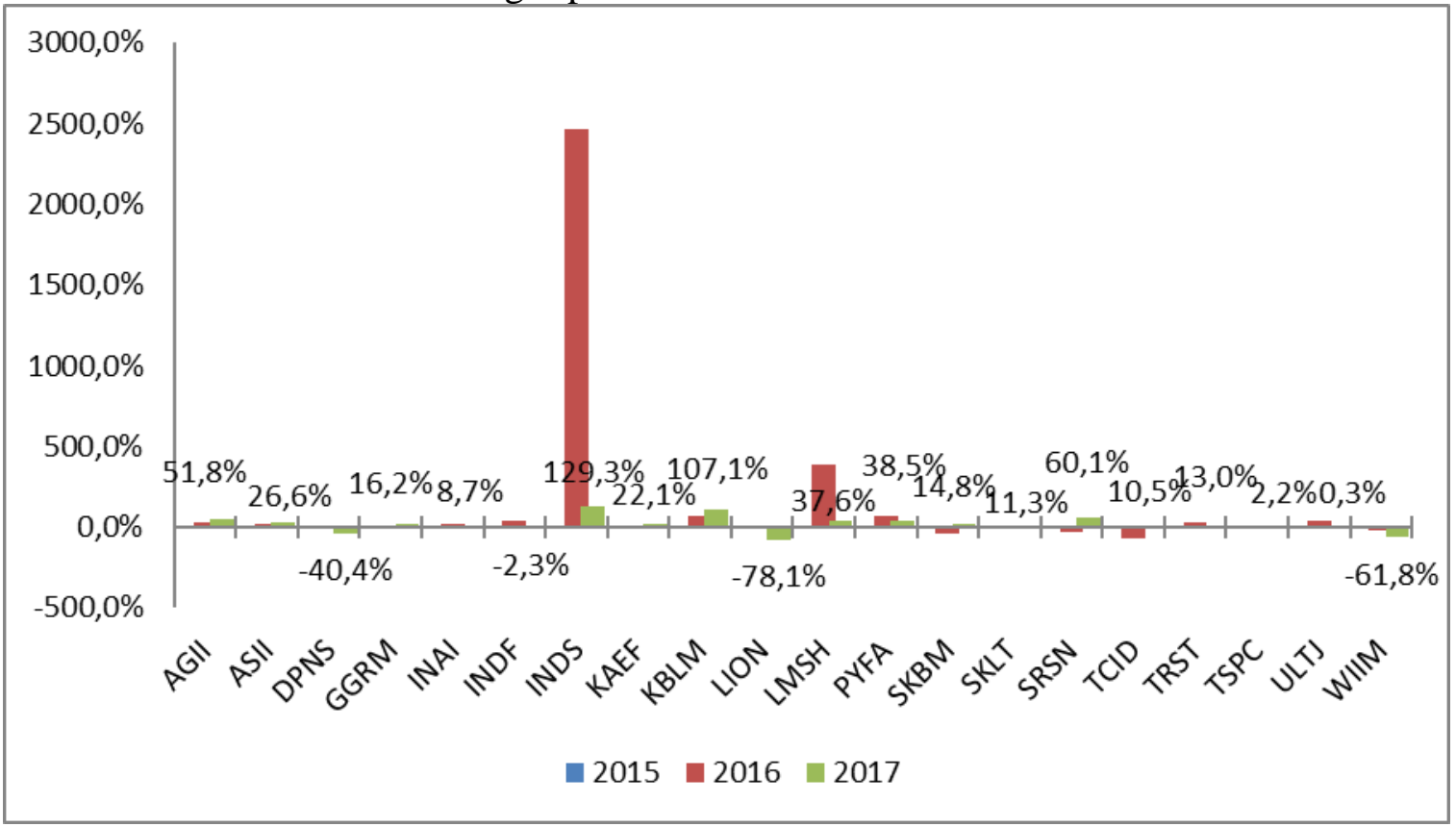

Sumber : Data Laporan Keuangan di BEI (telah diolah)

Berdasarkan gambar diatas, diketahui perusahaan manufaktur yang listing di Bursa Efek Indonesia Tahun 2015 sampai 2017 tercatat berfluktuatif setiap tahunnya. Hal ini dapat dilihat adanya laba terendah yang terjadi pada tahun 2017 yaitu pada PT Lion Metal Works Tbk (LION) sebesar $-78,1 \%$. Mengingat kondisi ekonomi yang selalu mengalami perubahan, maka dapat mempengaruhi kondisi perusahaan yang dapat 
dilihat dari labanya. Laba perusahaan rendah menunjukan bahwa kondisi keuangan perusahaan tersebut tidak baik dan juga akan mencerminkan kinerja perusahaan yang buruk. Hal itu berpengaruh besar bagi pihak yang berkepentingan terhadap perusahaan sebagai pemakai informasi keuangan.

Perusahaan yang besar dapat menunjukan kemampuan dalam melakukan penjualan dan mengelola asset yang dapat memperoleh laba. Selain itu, perusahaan yang besar juga menjanjikan kinerja yang lebih baik. Maka dari itu, ukuran perusahaan merupakan salah satu faktor yang dianggap mampu mempengaruhi kinerja keuangan perusahaan. Ukuran perusahaan menentukan penggunaan dana eksternal yang akan digunakan oleh perusahaan. Hal ini disebabkan karena perusahaan yang besar akan membutuhkan dana yang besar untuk dapat menjalankan perusahaan (Oktaviana, 2016). Kegiatan utama suatu perusahaan salah satunya yaitu penjualan karena angka penjualan yang tinggi mempengaruhi keuntungan dan meningkatkan aset perusahaan. Hasil penelitian yang dilakukan oleh Arisadi (2013) yang menyatakan bahwa peningkatan pada jumlah aset yang dimiliki perusahaan menunjukkan semakin bertambah ukuran perusahaan tersebut sehingga kenaikan ukuran perusahaan meningkatkan kinerja keuangan perusahaan (laba).

Dalam proses memaksimalkan kinerja keuangan perusahaan maka, pemilik perusahaan menyerahkan pengelolaan perusahaan kepada manajer agar dapat tercapainya tujuan utama perusahaan tersebut. Namun, dalam kenyataannya pihak manajemen perusahaan memiliki kepentingan terhadap kemakmuran dirinya sendiri yang bertentangan dengan tujuan utama tersebut. Masalah keagenan pun dihadapi para pemegang saham, dimana para pemegang saham kesulitan untuk memastikan bahwa dananya tidak disalahgunakan oleh manajemen perusahaan untuk mendanai kegiatan yang tidak menguntungkan para pemegang saham (Wulandari, 2006) dalam (Mahaputeri, 2014). Maka dari itu, masalah keagenan tersebut dapat dikurangi dengan adanya kepemilikan manajerial yang tinggi. Sehingga, kepemilikan manajerial memberi kesempatan manajer ikut terlibat didalam kepemilikan saham, dengan keterlibatan ini kedudukan antara manajer dengan pemegang saham sama agar dapat meningkatkan kinerja manajer. Hal ini didukung oleh Putra (2017) yang menyatakan bahwa semakin tinggi kepemilikan manajerial maka akan semakin tinggi juga kinerja keuangan.

Kinerja keuangan perusahaan pada penelitian ini diproksikan dengan Return on Equity (ROE). Semakin besar ROE yang dihasilkan dapat mencerminkan kemampuan perusahaan dalam menghasilkan keuntungan yang besar pula bagi pemegang saham (Novrianti, 2012). Karena pengukuran ROE merupakan variabel yang sangat penting untuk para investor sebelum berinvestasi yang menunjukan bahwa manajemen perusahaan mampu mengelola keuangan perusahaan tersebut dengan baik yang dapat menghasilkan keuntungan bagi para investor atas modal yang mereka investasikan. Investor perlu melakukan suatu penilaian untuk memutuskan suatu perusahaan memiliki kinerja yang baik atau tidak sehinga memerlukan informasi ROE yang akan membantu investor dalam menilai berbagai aspek dari posisi keuangan perusahaan. Oleh karena itu, perusahaan harus memperbaiki dan mengatasi persoalan agar dapat mempertahankan perusahaannya sehingga para investor tertarik untuk berinvestasi 
Masalah keagenan yang terjadi juga perlu adanya aspek pengendalian dari komite audit. Jumlah anggota komite audit yang besar mampu mensejajarkan kepentingan manajemen dan pemegang saham, Semakin besar ukuran komite audit, maka peran komite audit dalam mengendalikan dan memantau manajemen puncak akan semakin efektif (Yunizar, 2014). Karena, komite audit bertanggung jawab untuk mengawasi proses pelaporan keuangan. Dengan adanya komite audit maka proses pelaporan keuangan perusahaan akan termonitor dengan baik. Hasil penelitian yang menunjukan bahwa komite audit berpengaruh terhadap kinerja keuangan perusahaan dilakukan oleh Putra (2017) yang menyatakan bahwa menunjukkan bahwa adanya komite audit yang efektif dapat meningkatkan kinerja perusahaan karena dapat menekan terjadinya penyimpangan-penyimpangan akuntansi yang sering dilakukan oleh banyak perusahaan di Indonesia.

\section{Tinjauan Literatur \& Hipotesis}

\section{Kinerja Keuangan Perusahaan}

Kinerja perusahaan merupakan hasil akhir dari proses manajemen selama suatu periode ke periode yang lain (Samsul, 2006) dalam (Meitasari 2016). Penilaian terhadap kinerja perusahaan diperlukan karena kinerja merefleksikan kemampuan perusahaan dalam mengelola dan mengalokasikan sumber dayanya. Penelitian mengenai kinerja keuangan perlu dilakukan karena dapat merefleksikan keberhasilan suatu perusahaan dalam menghasilkan laba dan mengingat tujuan utama perusahaan adalah untuk mensejahterakan para pemegang saham dengan terus melipatgandakan kekayaan perusahaan (Meitasari, 2016).

Menurut Meitasari (2016) Kinerja perusahaan merupakan suatu gambaran tentang kondisi keuangan suatu perusahaan yang dianalisis dengan alat-alat analisis keuangan, sehingga dapat diketahui mengenai baik buruknya keadaan keuangan suatu perusahaan yang mencerminkan prestasi kerja dalam periode tertentu. Rasio keuangan merupakan salah satu bentuk informasi akuntansi yang penting dalam proses penilaiaan kinerja perusahaan, sehingga dengan rasio keuangan tersebut dapat mengungkapkan kondisi keuangan suatu perusahaan maupun kinerja yang telah dicapai perusahaan untuk suatu periode tertentu.

Perusahaan dengan persentase kepemilikan asing yang tinggi diduga dapat menigkatkan kinerja perusahaan karena manajemen dengan kepemilikan asing dapat lebih fokus dan lebih efisien dalam mengarahkan kegiatan operasional perusahaan, sehingga tujuan memaksimalkan profit dapat tercapai (Astuti, 2014).

Tujuan dilakukannya pengukuran kinerja perusahaan yaitu untuk mengetahui apakah hasil yang dicapai perusahaan telah sesuai dengan perencanaannya. Tujuan perusahaan akan tercapai jika kinerja perusahaan meningkat. Rasio profitabilitas mengukur kemampuan perusahaan menghasilkan keuntungan pada tingkat penjualan, asset, dan modal saham tertentu (Desiana, 2015).

Ada banyak rasio dalam mengukur kinerja perusahaan salah satunya yaitu Rasio Profitabilitas. Rasio profitabilitas rasio untuk mengukur seberapa besar kemampuan perusahaan memperoleh laba baik dalam hubungan penjualan, aset, maupun laba bagi modal sendiri (Desiana, 2015). Salah satunya yaitu return on equity (ROE).

Variabel kinerja perusahaan yang dalam penelitian ini dihitung dengan rasio return on equity (ROE), yaitu rasio yang menunjukkan berapa persen laba bersih 
setelah pajak terhadap ekuitas (modal) (Meitasari, 2016). ROE menggambarkan berapa besar pengembalian yang didapatkan investor untuk menanamkan modalnya dalam sebuah perusahaan, dengan demikian nilai ROE yang tinggi maka akan menarik para investor untuk menanamkan modalnya (Triastuty, 2017). Semakin tinggi ROE maka perusahaan dapat menghasilkan keuntungan yang tinggi pula bagi pemegang saham. ROE yang tinggi menunjukan kinerja keuangan perusahaan yang baik, hal ini menyebabkan para investor tertarik untuk menanamkan modalnya (Desiana, 2015).

Indikator kinerja keuangan yang diwakili oleh ROE yang secara statistik dapat mewakili konstruk kinerja keuangan perusahaan manufaktur di Indonesia (Baroroh, 2013).

\section{Ukuran Perusahaan}

Ukuran perusahaan merupakan hal yang penting dalam peningkatan kinerja keuangan perusahaan. Menurut Meriewaty dan Yuli (2005: 107) dalam Meitasari (2016) ukuran perusahaan juga merupakan salah satu faktor yang mempengaruhi kinerja keuangan perusahaan. Ukuran perusahaan menunjukkan besar kecilnya perusahaan yang dapat dilihat dari tingkat penjualan, jumlah tenaga kerja atau jumlah aktiva yang dimiliki perusahaan. Ukuran perusahaan yaitu suatu skala yang menentukan besar kecilnya perusahaan yang dapat dilihat dari nilai equity.

Ukuran perusahaan menunjukkan peningkatan aset pada masing-masing perusahaan manufaktur. Perusahaan besar yang telah listing di Indonesia mendapatkan keuntungan lebih dari kegiatan operasinya, dengan kata lain adanya peningkatan pada ukuran perusahaan dapat menaikkan profitabilitas perusahaan (Arisadi, 2013). Menurut Prasetyantoko dan Parmono (2008) dalam Arisadi (2013), hasil ini mempunyai makna bahwa kenaikan ukuran perusahaan meningkatkan kinerja keuangan perusahaan (laba).

Semakin besar ukuran perusahaan maka semakin besar pula dana yang dikelola oleh perusahaan tersebut. Perusahaan besar biasanya lebih memiliki peluang untuk meningkatkan kinerja perusahaan, sedangkan perusahaan kecil biasanya sulit untuk meningkatkan kinerja perusahaan (Desiana, 2015).

Ukuran perusahaan merupakan kekuatan finansial yang dimiliki oleh sebuah perusahaan dimana semakin besar aset yang dimiliki oleh perusahaan maka akan semakin mendapat perhatian di mata masyarakat. Dengan begitu, perusahaan akan termotivasi untuk selalu mempertahankan kinerjanya yaitu kinerja keuangannya (Dewi, 2017).

Menurut (Jogiyanto, 2003) dalam (Reyhan, 2014) Perusahaan yang besar dianggap mempunyai resiko yang lebih kecil dibandingkan dengan perusahaan yang kecil. Maka dari itu, investor biasanya lebih tertarik untuk menanamkan modalnya di perusahaan besar dianggap lebih mempertahankan dan meningkatkan kinerjanya.

Hasil penelitian Arisadi (2013) menunjukkan ukuran perusahaan berpengaruh terhadap kinerja keuangan. Secara lebih jelas, hasil penelitian Arisadi (2013) memberikan makna bahwa perusahaan dengan ukuran besar dan go public mempunyai akses yang besar ke sumber-sumber dana untuk membiayai investasinya dalam rangka meningkatkan labanya. Hal ini sejalan dengan Kamaruddin (2015) ukuran perusahaan berpengaruh terhadap kinerja keuangan. 
Ukuran besar kecilnya suatu perusahaan ikut mempengaruhi kapasitas dan kualitas kinerja keuangan yang dimiliki oleh perusahaan. Perusahaan besar dikenal memiliki kinerja keuangan yang lebih prima dibandingkan dengan perusahaan kecil. Perusahaan-perusahaan besar cenderung memiliki nama yang sudah lebih dikenal serta lebih mampu bersaing di tengah pasar yang sangat kompetitif. Semakin memadai aset yang dimiliki oleh perusahaan, hal itu akan menunjang perusahaan dalam meningkatkan penjualan sehingga perusahaan mengalami kenaikan laba.

\section{Kepemilikan Manajerial}

Kepemilikan manajerial didefinisikan sebagai tingkat kepemilikan saham pihak manajemen yang secara aktif ikut dalam pengambilan keputusan, misalnya seperti direktur, manajemen, dan komisaris. Kepemilikan manajerial memberi kesempatan manajer ikut terlibat didalam kepemilikan saham, sehingga dengan keterlibatan ini kedudukan antara manajer dengan pemegang saham sama. Dengan samanya kedudukan manajer dengan pemegang saham dapat efektif untuk meningkatkan kinerja manajer (Wahidahwati,2002) dalam (Putra, 2017).

Menurut Wahidahwati (2002) dalam Aluy (2017) mendefinisikan bahwa kepemilikan manajerial adalah pemegang saham dari pihak manajemen yang secara aktif ikut dalam pengambilan keputusan perusahaan (Direktur atau Komisaris). Kepemilikkan manajerial diukur dari jumlah presentase saham yang dimilikki manajer. Kepemilikan manajerial adalah presentase saham yang dimiliki manajer dan direksi suatu perusahaan (Aluy, 2017).

Kepemilikan manajerial merupakan salah satu aspek corporate governance dimana manajer terlibat dalam kepemilikan saham atau dengan kata lain manajer juga sebagai pemegang saham. Keterlibatan tersebut akan mendorong manajer untuk bertindak secara hati - hati karena manajer akan turut menanggung konsekuensi atas keputusan yang diambilnya. Selain itu, manajer akan termotivasi untuk meningkatkan kinerjanya dalam mengelola perusahaan (Dewi, 2017).

Menurut Ross (1999) dalam Hartono (2014) menyatakan bahwa semakin besar proporsi kepemilikan manajemen pada perusahaan, maka manajemen cenderung berusaha giat untuk kepentingan pemegang saham yang tidak lain dirinya sendiri. Sehingga dapat dikatakan kepemilikan saham oleh manajemen akan membuat manajemen termotivasi dalam meningkatkan kinerja perusahaan. Dengan adanya kepemilikan manajerial, pihak manajemen akan merasa ikut memiliki perusahaan karena segala konsekuensi atas keputusan yang diambil akan dirasakan pula oleh pihak manajemen. Hal ini akan membuat pihak manajemen lebih berhati-hati dalam mengelola perusahaan (Martsila, 2013).

Semakin besar kepemilikan saham oleh manajemen dalam perusahaan semakin produktif tindakan manajer dalam memaksimalkan kinerja perusahaan. Kepemilikan manajerial dapat menurunkan conflict of interest yang disebabkan antara pemilik dan manajer. Dengan adanya kepemilikan manajerial yang semakin besar dapat berimplikasi pada kinerja manajemen yang akan meningkat, sehingga dapat meningkatkan laba perusahaan dan berpengaruh terhadap kinerja perusahaan (Triastuty, 2017).

Kepemilikan manajerial yang terlalu tinggi akan berdampak buruk terhadap perusahaan karena manajer mempunyai posisi yang kuat dalam mengendalikan 
perusahaan yang mengakibatkan pemegang saham sulit mengendalikan tindakan yang dilakukan manajer. Hasil penelitian ini didukung oleh Dewi (2017) yang menyatakan bahwa Kepemilikan Manajerial tidak berpengaruh terhadap Kinerja Keungan. Manajemen sebagai pengelola perusahaan dan sekaligus pemilik saham dalam perusahaan membuatnya memiliki rangkap jabatan yaitu sebagai manajer (pengelola perusahaan) dan investor.

Menurut Putra (2017) Kepemilikan manajerial memiliki pengaruh positif terhadap terhadap kinerja keuangan. Kepemilikan manajerial memberi kesempatan manajer ikut terlibat didalam kepemilikan saham, sehingga dengan keterlibatan ini kedudukan antara manajer dengan pemegang saham sama. Dengan samanya kedudukan manajer dengan pemegang saham dapat efektif untuk meningkatkan kinerja manajer. Hal ini menunjukkan bahwa kepemilikan saham manajerial dapat membantu penyatuan kepentingan antara pemegang saham dengan manajer

\section{Komite Audit}

Ikatan Komite Audit Indonesia (IKAI) mendefinisikan komite audit sebagai berikut: "Suatu komite yang bekerja secara professional dan independen yang dibentuk oleh dewan komisaris" (Putra,2017). Menurut Putra (2017) Komite Audit adalah suatu komite yang dibentuk oleh dewan komisaris dan memiliki tugas dan tanggung jawab untuk melakukan pengawasan terhadap laporan keuangan, audit eksternal dan mengamati sistem pengendalian internal.

Keberadaan komite audit dapat memonitoring pihak manajer perusahaan sehingga dapat meminimumkan biaya agensi yang kemudian dapat membuat perusahaan lebih efesien sehingga dapat meningkatkan kinerja (Hartono, 2014).

Komite audit merupakan anggota eksternal perusahaan yang tidak berperan dalam pelaksanaan opersional perusahaan sehingga proses pengawasan dan pengevaluasian dapat berjalan dengan baik (Mulyadi, 2016). Komite audit yang merupakan jumlah anggota komite audit yang berperan dalam perusahaan tersebut (Mulyadi, 2016). Komite audit yang bertanggung jawab untuk mengawasi laporan keuangan, mengawasi audit eksternal, dan mengamati sistem pengendalian internal (termasuk audit internal) dapat mengurangi sifat opportunistic manajemen yang melakukan manajemen laba (earnings management) dengan cara mengawasi laporan keuangan dan melakukan pengawasan pada audit eksternal (Siallagan, 2006) dalam (Mulyadi, 2016). Komite audit diketuai oleh komisaris independen dan anggotanya dapat terdiri dari komisaris dan atau pelaku profesi dari luar perusahaan. Salah seorang anggota memiliki latar belakang dan kemampuan akuntasi dan atau keuangan.

Pengaturan mengenai jumlah komite audit bagi emiten dan perusahaan publik diatur dalam peraturan Bapepam-LK No.IX.I.5 tentang Pembentukan dan Pedoman Pelaksanaan Kerja Komite Audit. Dalam peraturan tersebut emiten dan perusahaan publik diwajibkan membentuk komite audit yang berjumlah sekurang-kurangnya tiga orang dimana salah satunya merupakan komisaris independen perusahaan dan bertindak sebagai ketua komite audit (Kemenkeu RI, 2010) dalam (Mulyadi, 2016).

Deskripsi mengenai anggota komite audit (COMAUD) secara modus diperoleh sebesar 3. Hal ini ini berarti bahwa secara umum banyak perusahaan sampel memiliki anggota komite audit yang berjumlah 3 orang. Jumlah komite audit yang paling sedikit adalah sebanyak 2 orang dan jumlah terbanyak adalah sebanyak 4 orang (Utomo, 2014). 
Komite audit sangat penting dalam rangka meningkatkan kinerja perusahaan, terutama dari aspek pengendalian (Efendi, 2005) dalam (Yunizar, 2014). Hal ini dikarenakan semakin besar ukuran komite audit, maka peran komite audit dalam mengendalikan dan memantau manajemen puncak akan semakin efektif (Yunizar, 2014).

Menurut Putra (2017) komite audit berpengaruh positif terhadap kinerja keuangan. Berdasarkan hasil tersebut bisa dikatakan bahwa perusahaan yang mengungkapkan komite audit memiliki citra positif dimata investor pada umumnya. Diharapkan dapat mengurangi konflik agensi sehingga laporan yang disampaikan kepada pihak-pihak yang berkepentingan dapat dipercaya sehingga dapat membantu meningkatkan kinerja keuangan. Hal ini menunjukkan bahwa adanya komite audit yang efektif dapat meningkatkan kinerja perusahaan karena dapat menekan terjadinya penyimpangan - penyimpangan akuntansi yang sering dilakukan oleh banyak perusahaan di Indonesia. Hal ini sejalan dengan hasil penelitian Effendi (2005) dalam Putra (2017) yang menyimpulkan bahwa keberadaan komite audit sangat penting dalam rangka meningkatkan kinerja perusahaan, terutama dari aspek pengendalian. Hal ini dikarenakan semakin besar ukuran komite audit, maka peran komite audit dalam mengendalikan dan memantau manajemen puncak akan semakin efektif.

\section{METODE}

Jenis data yang digunakan dalam penelitian ini adalah data sekunder yang diambil dari laporan tahunan 2015 sampai dengan 2017 yang sudah dipublikasi di Bursa Efek Indonesia (www.idx.co.id). Jumlah perusahaan yang dijadikan sample perusahaan adalah sebanyak 35 yang berkategori perusahaan sektor manufacture.

Tabel 1. Kriteria Pengambilan Sampel

\begin{tabular}{l|c}
\hline \multicolumn{1}{c|}{ Kriteria } & $\begin{array}{c}\text { Jumlah } \\
\text { Perusahaan }\end{array}$ \\
\hline $\begin{array}{l}\text { Perusahaan Manufaktur yang terdaftar di Bursa Efek } \\
\text { Indonesia periode 2015-2017. }\end{array}$ & 147 \\
\hline $\begin{array}{l}\text { Perusahaan Manufaktur yang tidak menerbitkan laporan } \\
\text { keuangan dan tahunan secara berturut - turut selama periode } \\
\text { 2015-2017. }\end{array}$ & $(21)$ \\
\hline $\begin{array}{l}\text { Perusahaan Manufaktur yang mengalami kerugian pada } \\
\text { periode 2015-2017. }\end{array}$ & $(22)$ \\
\hline $\begin{array}{l}\text { Perusahaan Manufaktur yang tidak menggunakan mata uang } \\
\text { rupiah secara konsisten pada periode 2015-2017. }\end{array}$ & $(60)$ \\
\hline $\begin{array}{l}\text { Perusahaan Manufaktur yang menerbitkan laporan keuangan } \\
\text { dan tahunan secara tidak lengkap selama periode 2015-2017. }\end{array}$ & $\mathbf{2 0}$ \\
\hline Jumlah sampel penelitian selama periode 2015 - 2017 & \\
\hline
\end{tabular}

Sumber : www.idx.co.id (data diolah 2017) 
Berdasarkan hasil pengambilam sampel di atas maka jumlah sampel dalam penelitian ini sebanyak 60 sampel selama 5 tahun yaitu dari tahun 2015-2017

Adapun metode pengukuran variabelnya dapat dilihat pada tabel berikut:

\begin{tabular}{|r|l|c|c|}
\hline No & \multicolumn{1}{|c|}{ Variabel } & Indikator & Skala \\
\hline 1. & $\begin{array}{l}\text { Kinerja Keuangan } \\
\text { Perusahaan }(\mathrm{Y})\end{array}$ & Return On Equity $=\frac{\text { Laba Bersih }}{\text { Ekuitas }} \times 100 \%$ \\
\hline 2. & $\begin{array}{l}\text { Ukuran Perusahaan }\left(\mathrm{X}_{1}\right) \\
\text { Rasio }\end{array}$ & $\begin{array}{c}\text { Size }=\text { Logaritma natural dari total } \\
\text { asset }\end{array}$ & Rasio \\
\hline 3. & $\begin{array}{l}\text { Kepemilikan Manajerial } \\
\left(\mathrm{X}_{2}\right)\end{array}$ & $\begin{array}{c}\text { Total Saham Beredar } \\
\text { Iumlah saham manajerial } \\
\text { ase }\end{array}$ \\
\hline 4. & Komite Audit $\left(\mathrm{X}_{3}\right)$ & $=\sum$ Anggota Komite Audit & Nominal \\
\hline
\end{tabular}

Metode analisis data yang digunakan tidak seperti regresi biasanya, regresi data panel melalui tahapan penentuan model estimasi model regresi dengan menggunakan data panel dapat dilakukan melalui tiga pendekatan, antara lain:

1. Common Effect Model, Analisis model common effect merupakan teknik yang paling sederhana mengansumsikan bahwa data gabungan yang ada menunjukan data yang sesungguhnya. Dalam pendekatan estimasi ini, tidak diperlihatkan dimensi individu maupun waktu. Diasumsikan bahwa perilaku data antar perusahaan sama dalam berbagai kurun waktu. (Winarno, 2015: 9.14)

2. Fixed Effect Model, Menurut winarno (2015: 9.10) diperlukan suatu model yang dapat menunjukan perbedaan konstanta antar objek meskipun dengan koefisien yang sama model ini dikenal dengan nama model efek tetap atau fixed effect

3. Random Effect Model (Winarno, 2015). Selain dengan metode efek tetap, kita juga dapat menganalisis data panel dengan menggunakan efek random. Efek random digunakan untuk mengatasi kelemahan metode efek tetap yang menggunakan variabel semu, metode efek random menggunakan residual, yang diduga memiliki hubungan antarwaktu dan antar objek (Winarno, 2015: 9.17)

Setelah melakukan uji-uji dalam mencari pendekatan estimasi yang terbaik dalam regresi data panel maka selanjutnya akan dilakukan analisis sebagai berikut:

1. Uji asumsi klasik menggunakan; a) Uji multikolinearitas, bertujuan untuk menguji apakah dalam model regresi panel ditemukan adanya korelasi antar variabel independen. Untuk menguji masalah multikolinearitas dapat melihat matriks korelasi dari variabel bebas, jika terjadi koefisien korelasi lebih dari 0,80 maka terdapat multikolinearitas (Gujarati, 2007); b) uji heteroskedastisitas, dilakukan untuk mengetahui ada atau tidaknya ketidaksamaan varian dari residual model regresi data panel. 
Ketentuan yang digunakan, jika nilai probabilitasnya tidak signifikan secara statistik pada derajat $5 \%$ maka hipotesis nol diterima, yang berati tidak ada heteroskedastisitas dalam model (Gujarati, 2007).

2. Analisis regresi data panel, adalah analisis regresi dengan struktur data yang merupakan data panel. Umumnya pendugaan parameter dalam analisis regresi dengan data cross section dilakukan menggunakan pendugaan metode kuadrat terkecil atau disebut Ordinary Least Square (OLS). Data panel (pooled data) diperoleh dengan cara menggabungkan data time series dengan cross section.

$$
Y_{i t}=\alpha+\beta_{1} X_{1 i t}+\beta_{2} X_{2 i t}+\beta_{3} X_{3 i t}+\ldots+\beta_{n} X_{n i t}+e_{i t}
$$

3. Uji $\mathrm{R}^{2}$ koefisien determinasi dilakukan untuk melihat seberapa jauh kemampuan model dalam menerangkan variasi variabel bebas mempengaruhi variabel terikat (Ghozali, 2005). Nilai $\mathrm{R}^{2}$ berada antara 0 dan 1. Semakin mendekati 1 atau 100\% maka semakin besar pengaruh variabel independen terhadap variabel dependen.

4. Uji statistik, untuk menguji apakah pengaruh signifikan atau tidak maka perlu dihitung nilai t dengan interval keyakinan (level of signification) $95 \%, \alpha=5 \%$ dan derajat kebebasan (degree of freedom) atau dengan melihat nilai signifikansi dibandingkan dengan alpha $5 \%$.

\section{Hasil Analisis \& Pembahasan}

Berdasarkan pengujian perpasangan terhadap ketiga model regresi data panel tersebut, seperti yang ditunjukkan dalam tabel 2, dapat disimpulkan bahwa Random Effect Model (REM) dalam regresi data panel dapat digunakan lebih lanjut untuk menganalisis secara simultan dan parsial apakah keputusan Ukuran Perusahaan (LnTA), Kepemilikan Manajerial (KM) dan Komite Audit $(K A)$ berpengaruh terhadap Kinerja keuangan perusahaan (ROE) pada perusahaan sektor Manufacture.

Tabel 2. Kesimpulan Pengujian Model Regresi Data Panel

\begin{tabular}{|c|l|c|c|c|}
\hline No. & \multicolumn{1}{|c|}{ Metode } & Pengujian & Hasil \\
\hline 1 & Uji Chow & CEM vs FEM & $\begin{array}{c}\text { Prob.Cross-section } \\
\text { Chi-square } \\
0.00<0,05(\alpha)\end{array}$ & FEM \\
\hline 2 & Uji Hausman & FEM vs REM & $\begin{array}{c}\text { Prob.Cross-section } \\
\text { random } 0,76> \\
0,05(\alpha)\end{array}$ & REM \\
\hline 3 & Uji Lagrange Multiplier & REM vc CEM & $\begin{array}{c}\text { Cross-section } \\
\text { Breusch-Pagan } \\
0.00<0,05(\alpha)\end{array}$ & REM \\
\hline
\end{tabular}

Sumber: Hasil EViews 9, data diolah (2017)

Karena model yang terpilih adalah random effect maka tidak diperlukan uji asumsi klasik karena persamaan dalam model random effect sudah menggunakan metode Generalized Least Square (GLS) (Widarjono,2013). 
Berdasarkan hasil olah data dengan menggunakan Eviews 9.0, dapat dilihat pada tabel di bawah ini.

Tabel 3. Random Effect Model

\begin{tabular}{|c|c|c|c|c|}
\hline Variable & Coefficient & Std. Error & t-Statistic & Prob. \\
\hline $\mathrm{C}$ & -0.452320 & 0.197697 & -2.287943 & 0.0259 \\
\hline$\underline{\text { UP }}$ & 0.011767 & 0.006819 & 1.725573 & 0.0899 \\
\hline $\mathrm{KM}$ & 0.080427 & 0.077348 & 1.039809 & 0.3029 \\
\hline \multirow[t]{2}{*}{$\mathrm{KA}$} & 0.064107 & 0.023841 & 2.688950 & 0.0094 \\
\hline & & & S.D. & Rho \\
\hline \multicolumn{3}{|l|}{$\begin{array}{l}\text { Cross-section random } \\
\text { Idiosyncratic random }\end{array}$} & $\begin{array}{l}0.053909 \\
0.038714 \\
\end{array}$ & $\begin{array}{l}0.6597 \\
0.3403 \\
\end{array}$ \\
\hline \multicolumn{5}{|l|}{ Weighted Statistics } \\
\hline $\begin{array}{l}\text { R-squared } \\
\text { Adjusted R-squared } \\
\text { S.E. of regression } \\
\text { F-statistic } \\
\text { Prob(F-statistic) }\end{array}$ & $\begin{array}{l}0.184828 \\
0.141158 \\
0.038308 \\
\mathbf{4 . 2 3 2 3 7 4} \\
\mathbf{0 . 0 0 9 1 2 2}\end{array}$ & \multicolumn{2}{|c|}{$\begin{array}{l}\text { Mean dependent var } \\
\text { S.D. dependent var } \\
\text { Sum squared resid } \\
\text { Durbin-Watson stat }\end{array}$} & $\begin{array}{l}0.034343 \\
0.041336 \\
0.082179 \\
1.477482\end{array}$ \\
\hline
\end{tabular}

$R O E=-0,452+0,011 \mathrm{UP}+0,08 K M+0,06 K A+e$

Mengacu pada tabel di atas, maka dapat dibuat persamaan regresi data panel $(\boldsymbol{R O E}=-0,452+0,011 \mathrm{UP}+0,08 K M+0,06 K A+e)$. Nilai variabel Ukuran perusahaan, Kepemilikan Manajerial dan Komite audit yang positif menggambarkan hubungan yang searah terhadap kenaikan nilai perusahaan sebesar 0,011, 0,08 dan 0,06.

Nilai Adjusted R-squared sebesar 0,14, menunjukkan bahwa variasi perubahan/ kontribusi kinerja keuangan (ROE) dapat dijelaskan oleh UP, KM, KA sebesar 14\%, sementara sisanya dijelaskan oleh variabel-variabel lain yang tidak diteliti dalam penelitian ini.

Adapun dari hasil uji statistic (hipotesis t) di atas menunjukkan bahwa Ukuran perusahaan (Ln Total Asset) tidak berpengaruh terhadap kinerja keuangan perusahaan (ROE) dengan probabilitas $(0,08>0,05)$ dimana dapat dijelaskan bahwa total aset bukan menjadi hal yang utama bagi perusahaan melainkan strategi perusahaan untuk memperoleh laba. Strategi perusahaan yang kurang baik dapat memberikan dampak buruk bagi perusahaan dan tidak bisa memperoleh laba yang cukup sehingga mengakibatkan tingkat kepercayaan investor lebih kecil. Jadi dapat disimpulkan bahwa besar kecilnya ukuran perusahaan tidak dapat menjadi jaminan atas kinerja keuangan perusahaan yang baik.

Begitupun untuk variabel kepemilikan manajerial yang hasilnya menunjukkan tidak berpengaruh terhadap kinerja keuangan (ROE) dengan 
probabilitas $(0,3>0,05)$. Kepemilikan Manajerial merupakan situasi dimana manajer memiliki saham perusahaan sekaligus pemegang saham perusahaan. Hal tersebut menekankan mengenai agency theory dalam pendekatan teori ini kumpulan kontrak antara pemilik saham atau sumber daya ekonomis dan manajer yang mengurus penggunaan dan pengendalian sumber daya dalam sebuah perusahaan tersebut dapat dilihat bahwa pada hubungan agensi terdapat hubungan kontraktual dimana pemilik saham sebagai principal menunjuk dan menginginkan manajer atau agent untuk mengelola sumber daya yang dimiliki oleh principal dalam sebuah perusahaan. Namun demikian, dalam teori agensi juga dikatakan bahwa lama-kelamaan para agent tidak dapat lagi bertindak sesuai dengan kepentingan principal dan cenderung untuk bertindak sesuai kepentingan agent. Walaupun terjadi perbedaan kepentingan antara principal dan agent, principal dapat menjaga atau membatasi perbedaan kepentingan dengan agent agar tetap pada jalur yang sama.

Sementara itu komite audit (KA) memiliki pengaruh terhadap kinerja keuangan $(\mathrm{ROE})$ dengan probabilitas $(0,0094<0,05)$. Berdasarkan hasil tersebut bisa dikatakan bahwa perusahaan yang memiliki komite audit mempunyai citra positif dimata investor pada umumnya. Diharapkan dapat mengurangi konflik agensi sehingga laporan yang disampaikan kepada pihak-pihak yang berkepentingan dapat dipercaya sehingga dapat membantu meningkatkan kinerja keuangan perusahaan. Hasil penelitian ini sejalan dengan penelitian Putra (2017) yang mana Komite Audit berpengaruh positif terhadap Kinerja Keuangan Perusahaan. Tetapi bertolak belakang dengan penelitian Dewi (2017) yang mana hasil penelitiannya Komite Audit berpengaruh positif terhadap Kinerja Keuangan Perusahaan.

\section{Kesimpulan}

Berdasarkan hasil analisis data dan pembahasan yang telah dilakukan peneliti mengenai pengaruh Ukuran Perusahaan, Kepemilikan Manajerial dan Koite Audit terhadap Kinerja keuangan perusahaan (ROE) pada perusahaan sektor Manufaktur yang terdaftar di BEI. Maka dapat dikemukakan beberapa kesimpulan sebagai berikut; 1) Ukuran Perusahaan dan Kepemilikan Manajerial tidak memiliki pengaruh terhadap kinerja keuangan perusahaan; 2) Komite Audit memiliki pengaruh terhadap kinerja keuangan perusahaan; 3) sementara itu secara simultan variabel-variabel independen dalam penelitian ini (UP, KM dan KA) memiliki pengaruh terhadap kinerja keuangan perusahaan (ROE). Ditunjukkan dengan nilai prob (F-statistic) 0,009 < 0,05. 


\section{Daftar Pustaka}

Ajeng Asmi Mahaputeri, I.Kt.Yadnyana, E-Jurnal Akuntansi Universitas Udayana. 9.1 (2014): 58-68, ISSN: 2302-8556

Yunita Castelia Arisadi, Djumahir, Atim Djazuli, Universitas Brawijaya Malang Jurnal Aplikasi Vol 11, No 4, Tahun 2013 ISSN: 1693 - 5241

Damodar N. Gujarati.2007. Dasar-Dasar Ekonometrika. Edisi Ketiga,

Harahap. Sofyan Syafari. 2006. Analisis Kritis Atas Laporan Keuangan. Edisi Pertama. Jakarta: PT. Raja Grafindo Persada.

Jogiyanto, 2000.Teori Portofolio dan Analisis Investasi, Edisi Kedua ,BPFE,. Yogyakarta

Agus Widarjono. (2013). Ekonometrika: Pengantar dan aplikasinya, Ekonosia, Jakarta.

Rendy Irawan Yunizar, Shiddiq Nur Rahardjo, Universitas Diponegoro, Diponegoro Journal of Accounting Volume 3, Nomor 4, Tahun 2014, Halaman 1-10. ISSN: 2337-3806

Winarno, wing wahyu. 2015. Analisis Ekonometrika dan statistik dengan Eviews. Yogyakarta.

www.idx.go.id

Wikipedia 